\title{
がん治療標的としてのがん幹細胞と標的薬剤の探索
}

\author{
馬島哲夫
}

\section{Cancer Stem Cells (CSCs) as a Rational Therapeutic Cancer Target, and Screening for CSC-targeting Drugs}

\author{
Tetsuo Mashima \\ Division of Molecular Biotherapy, Cancer Chemotherapy Center, Japanese Foundation for \\ Cancer Research; 3-8-31 Ariake, Koto-ku, Tokyo 135-8550, Japan.
}

(Received September 6, 2016)

\begin{abstract}
The emergence of drug resistance is a major obstacle to the successful pharmacological treatment of cancer. Tumor heterogeneity is one of the key factors underlying drug resistance. Cancer cell heterogeneity in tumors is caused by genetic mutation and by the existence of cancer stem cells (CSCs). CSCs are defined as a subpopulation of highly tumorigenic cancer cells with self-renewal activity. It has been reported that various types of cancer involve CSCs, and that CSCs are generally resistant to anticancer drugs. Therefore, CSC-targeting agents could allow for more effective pharmacological treatment of cancer. Using a comprehensive gene expression study and functional genomic approach, we are trying to identify CSC-specific survival factors, as well as candidate compounds that interfere with CSC-selective survival signaling. These CSC-targeting drugs could be promising new therapeutic agents which would suppress the emergence of drugresistant cells and enhance the effect of antitumor agents.
\end{abstract}

Key words_ cancer stem cell; therapeutic target; functional genomics

\section{1. はじめに}

がん治療において，転移浸潤などのために外科的 切除が適用できないがんや再発がんの治療等では, 薬物療法が不可欠である. がんの薬物療法において は, 古典的な化学療法剤とともに近年, がん選択的 に発現するシグナル分子を標的とした分子標的薬が 臨床現場に導入され，これらが治療成績の向上につ ながっている。しかしながら，こうした薬物療法で は, 多くの場合, 薬物治療後ある一定期間の後に, 薬剤抵抗性となったがんが再発する。この薬剤耐性 の機序としては, 薬剂投与の過程で, がん細胞に遺 伝子変異などが生じ，これが原因となって薬剤抵抗 性を獲得する，いわゆる「獲得耐性」が主要因と考 えられてきた。 しかし近年，腫瘍組織を形成するが ん細胞には多様性があることが明らかになり，この 腫瘍組織内のがん細胞の不均一性が, 薬剤抵抗性や

公益財団法人がん研究会がん化学療法センター分子生 物治療研究部 (T135-8550 東京都江東区有明 3-8-31) e-mail: tmashima@jfcr.or.jp

本総説は, 日本薬学会第 136 年会シンポジウムS06 で 発表した内容を中心に記述したものである。
再発に大きく寄与していることがわかってきた.す なわち, 腫瘍中のがん細胞に薬剂抵抗性の細胞が既 に存在し, それが選択されて薬剂投与後に残存し, 再発に寄与するという考え方である.

\section{2. 制がん剂抵抗性・再発の要因としてのがん幹} 細胞

腫瘍内の細胞不均一性は, 主に以下の 2 つの要因 により生じると考えられている。1つは，遺伝子変 異の多様性である.がん細胞はゲノムが不安定であ るため, 多くの遺伝子変異がゲノム上に蓄積されて いるが，腫瘍組織内の個々のがん細胞は異なる遺伝 子変異を有する細胞集団であり，この中で薬剤耐性 に係わる変異を有する細胞が，薬剂投与後早期に出 現する薬剂抵抗性に係わることが実際に示されてい る. 1)

他方, 腫瘍内の細胞不均一性は, このような遺伝 子変異のみによらず, 細胞の可塑性にも起因すると 考えられており，その制御のキーとなるのが，がん 幹細胞，ないしは幹細胞様のがん細胞である. 腫瘍 内には，高い自己複製能・多分化能 - 高い造腫瘍性 を備えた少数の細胞が存在することが, 白血病や乳 


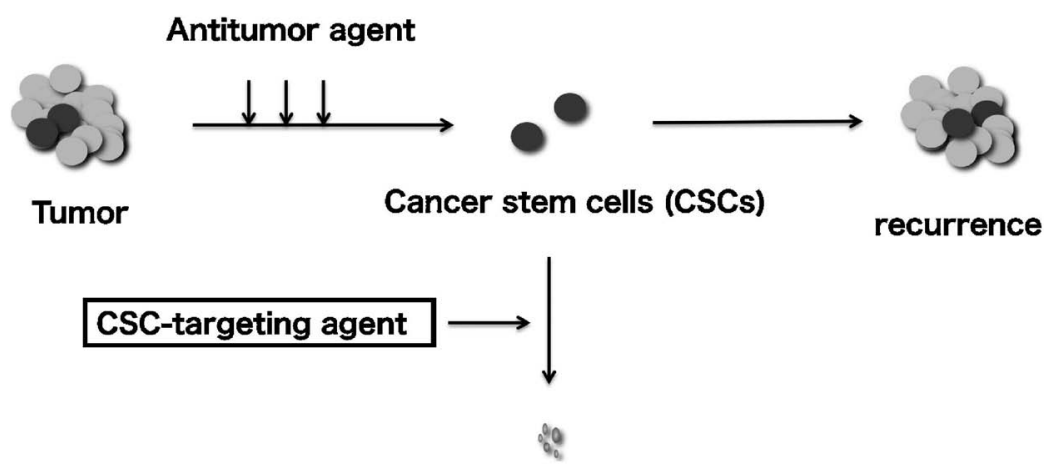

Fig. 1. Combinational Treatment of Antitumor Agents and Cancer Stem Cell (CSC)-targeting Agents as a Strategy to Prevent Tumor Recurrence

がんなど多くの固形がんで報告されており，これら

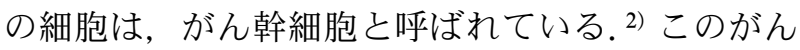
幹細胞は, 細胞増殖が遅く休止状態にあることや薬 剤トランスポーターが高発現していることが報告さ れており，これらにより種々の制がん剂に抵抗性で あると考えられている. したがって，がん幹細胞を 選択的に抑制する薬剤を開発し既存の制がん剂等と 併用することができれば，薬剤抵抗性の出現が抑え られ, 治療成績の大きな向上が期待されると考えら れている (Fig. 1).

\section{3. がん幹細胞選択的な生存因子や標的薬剤}

がん幹細胞については，これまでの研究から，特 異的に発現するマーカー分子やシグナル分子が報告 されている．細胞表面抗原であるCD44，とくにそ のスプライシング・バリアントである CD 44v は, 多くのがん種においてがん幹細胞マーカーとされる.

$\mathrm{CD} 44 \mathrm{v}$ は，シスチン・トランスポーターである $\mathrm{xCT}$ と結合し, シスチンの取り込みを充進して, 細胞内の抗酸化物質であるグルタチオン生成を促進 し, 酸化ストレスの抑制やがん幹細胞の生存に係わ ることが示されている. ${ }^{3)}$ またこの $\mathrm{xCT}$ の選択的な 阻害剂であるスルファサラジンは，がん幹細胞であ る CD44v 陽性細胞に選択的な作用を示すことから 現在, その臨床治験が進められている。そのほかに も, STAT3 経路等を標的としてがん幹細胞に作用 する薬剤であるナプカシン (BBI608) や，がん幹 細胞の維持に重要な役割を果たす maternal embryonic leucine zipper kinase (MELK) 阻害剤であ る OTS1674) などが，臨床治験中である。ただし， がん幹細胞がどのような細胞内シグナル伝達や生存 因子によって維持されているのかについては，いま
だ不明な点が多い. 特に, がん幹細胞のマーカー分 子やその性質は，がん種によって様々であることか ら，がん種毎，あるいは同一のがん種においてもサ ブタイプ毎に，がん幹細胞の性質やその違いを明確 にしていく必要がある，その上で，がん幹細胞特異 的な生存維持機構の更なる解明やそれを標的とした 薬剂の探索や開発が重要であると考えられる.

4. 前立腺がん幹細胞の生存因子とその生存経路 に作用する薬剤探索

筆者らは，わが国において急増している前立腺が んや主要ながんである消化器がん等のがん細胞株や 患者腫瘍組織から取得したがん細胞を用いて, 薬剂 抵抗性に係わるがん幹細胞分画の分離・同定を進め るとともに，新しい治療ターゲット分子の同定を目 指して，がん幹細胞の選択的生存因子の探索を行つ ている. 前立腺がんにおいては, がん幹細胞の性質 を持つ細胞として CD44 / CD133 陽性細胞や, CD151/CD166/TRA1-60 陽性細胞などが同定され ている. 前立腺がんの多くはアンドロゲン（男性ホ ルモン）受容体を発現しており，アンドロゲン依存 性増殖を示す。このため, その薬物療法にはアンド ロゲン依存性シグナル伝達経路を阻害する抗アンド ロゲン薬が用いられる。しかし前立腺がん幹細胞 は，アンドロゲン依存性シグナルが低下しているた め，これらの薬物に抵抗性であるとされている，筆 者らは, CD151/TRA1-60 陽性細胞を前立腺がん細 胞より分離し，それががん幹細胞の性質である高い 腫瘍形成能やスフェア増殖能を持つことを確認し た.さらに, RNAi スクリーニングにより, CD151/ TRA1-60 陽性細胞の増殖・生存に選択的に係わる 分子を探索した。 その結果, 前立腺がん幹細胞の選 


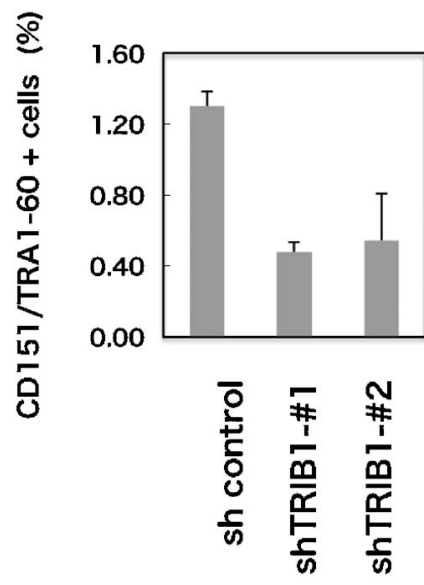

Fig. 2. Decrease of Cancer Stem Cell Population by TRIB1 Inhibition

Prostate cancer PC3 cells were infected with virus expressing shRNAs targeting TRIB1 or control shRNA. Percentage of cancer stem-like CD151/ TRA1-60 cells in PC3 cells were examined. Error bar indicates S.D. of the data.

択的生存因子としてシグナル伝達のアダプター分子 である tribbles pseudokinase 1 （TRIB1）を同定し た. ${ }^{5)}$ TRIB1 の short hairpin RNA（shRNA）による 発現抑制は，前立腺がん細胞内の CD151/TRA1-60 陽性細胞率を減少させ（Fig. 2)，さらに腫瘍形成 を抑制した。また，前立腺がんにおいては，TRIB1 の下流のシグナル分子として，小胞体ストレスシャ ペロンである glucose-regulated protein 78 (GRP78/ Bip）が係わっていることも見い出した．前立腺が 几腫瘍組織における TRIB1 発現を検討すると，そ の発現には不均一性が認められ，一部の細胞におい て TRIB1 が高く発現していた。 さらに最近，前立 腺がん腫瘍組織における TRIB1 高発現が再発・転

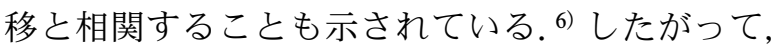
TRIB1 は前立腺がん幹細胞の生存維持に係わり, がんの再発を規定する分子であると考えられる.

TRIB1 はまた, 転写因子 CCAAT / enhancerbinding protein $(\mathrm{C} / \mathrm{EBP})$ の発現制御や mitogenactivated protein (MAP) キナーゼ経路の制御に係 わり，白血病などのがん遺伝子としての役割も報告 されている.7)こうしたことから TRIB1 は，がんに おける有望な治療標的分子であると考えられる。一 方，薬剤探索においては一般に，酵素活性を持ち， 阻害剂が開発し易い ‘druggable target’分子とそ うでない分子があるとされている。TRIB1 はシグ ナル伝達のアダプター分子であり，特定の酵素活性 を持たないため，TRIB1 分子自体を標的とした薬
剤の探索は容易ではない。そこで筆者らは現在, TRIB1 が制御する生存シグナルに作用する化合物 の探索を進めている。これに関しては，近年，web 上で利用可能な公的データベースが拡充してきてお り，化合物に関しても，米国ボストンの Broad Institute による Connectivity Map (http://portals. boradinstitue.org/cmap) ${ }^{8)}$ や，筆者らの構築した制 がん剂関連遺伝子発現データベース JFCR_LinCAGE (link between chemotherapeutic agent and gene expression) (http://scads.jfcr.or.jp/db/cs / index_j.html) ${ }^{9)}$ など，薬剤の標的分子経路を反映す る遺伝子発現変動データ（遺伝子シグネチャー）や それに基づく解析ツールが構築されてきた．筆者ら は，前立腺がん細胞において，TRIB1 を発現抑制 した際に変動する遺伝子群（遺伝子シグネチャー） を取得した。ささら，これを各種 website における 化合物処理後の変動遺伝子シグネチャーと重ね合わ せ，その類似性を検索することで，前立腺がん幹細 胞において，TRIB1 を介した生存シグナルに作用 する化合物の探索を進め，候補化合物を見い出して いる.

\section{5. まとめ}

がんの不均一性やその要因としてのがん幹細胞を 治療標的とした薬剤は，既存の制がん剂の効果を増 強するとともに，薬剂耐性の出現や再発を抑える薬 剂として今後期待される。しかし，がん幹細胞のバ イオロジー自体，まだまだ十分に明らかでないとこ ろが多い。このような基礎知見の拡充を通じて，薬 剂開発のための基盤情報構築の推進につなげていけ ればと考えている.

謝辞本研究は, 公益財団法人がん研究会がん 化学療法センター分子生物治療研究部において, 清 宮啓之部長を始めとするメンバーの方々のご指導や ご協力の下に進められたものであり，ここにすべて の共同研究者，研究協力者の方々に深謝いたします.

利益相反＼cjkstart開示すべき利益相反はない.

\section{REFERENCES}

1) Hata A. N., Niederst M. J., Archibald H. L., Gomez-Caraballo M., Siddiqui F. M., Mulvey H. E., Maruvka Y. E., Ji F., Bhang H. E., 
Radhakrishna V., Siravegna G., Hu H., Raoof S., Lockerman E., Kalsy A., Lee D., Keating C. L., Ruddy D. A., Damon L. J., Crystal A. S., Costa C., Piotrowska Z., Bardelli A., Iafrate A. J., Sadreyev R. I., Stegmeier F., Getz G., Sequist L. V., Faber A. C., Engelman J. A., Nat. Med., 22, 262-269 (2016).

2) Magee J. A., Piskounova E., Morrison S. J., Cancer Cell, 21, 283-296 (2012).

3) Ishimoto T., Nagano O., Yae T., Tamada M., Motohara T., Oshima H., Oshima M., Ikeda T., Asaba R., Yagi H., Masuko T., Shimizu T., Ishikawa T., Kai K., Takahashi E., Imamura Y., Baba Y., Ohmura M., Suematsu M., Baba H., Saya H., Cancer Cell, 19, 387-400 (2011).

4) Alachkar H., Mutonga M. B., Metzeler K. H., Fulton N., Malnassy G., Herold T., Spiekermann K., Bohlander S. K., Hiddemann W.,
Matsuo Y., Stock W., Nakamura Y., Oncotarget, 5, 12371-12382 (2014).

5) Mashima T., Soma-Nagae T., Migita T., Kinoshita R., Iwamoto A., Yuasa T., Yonese J., Ishikawa Y., Seimiya H., Cancer Res., 74, 4888-4897 (2014).

6) Lin Z. Y., Huang Y. Q., Zhang Y. Q., Han Z. D., He H. C., Ling X. H., Fu X., Dai Q. S., Cai C., Chen J. H., Liang Y. X., Jiang F. N., Zhong W. D., Wang F., Wu C. L., Int. J. Cancer, 135, 541-550 (2014).

7) Yokoyama T., Nakamura T., Cancer Sci., 102, 1115-1122 (2011).

8) Lamb J., Nat. Rev. Cancer, 7, 54-60 (2007).

9) Mashima T., Ushijima M., Matsuura M., Tsukahara S., Kunimasa K., Furuno A., Saito S., Kitamura M., Soma-Nagae T., Seimiya H., Dan S., Yamori T., Tomida A., Cancer Sci., 106, 909-920 (2015). 